\title{
PENGARUH VOLUME PENJUALAN KAMAR DAN BIAYA OPERASIONAL TERHADAP LABA BERSIH PADA HOTEL GRAND WIJAYA SINGARAJA TAHUN 2014-2016
}

\author{
Kadek Marlita Dewi \\ Jurusan Pendidikan Ekonomi, Fakultas Ekonomi \\ Universitas Pendidikan Ganesha \\ Singaraja, Indonesia
}

e-mail: marlitadewikadek@gmail.com

\begin{abstract}
Abstrak
Penelitian ini bertujuan untuk mengetahui pengaruh volume penjualan kamar dan biaya operasional terhadap laba bersih baik secara parsial maupun simultan pada Hotel Grand Wijaya Singaraja tahun 2014-2016. Jenis penelitian ini adalah penelitian kausal dengan pendekatan kuantitatif. Data dikumpulkan dengan metode dokumentasi. Data dianalis menggunakan regresi linier berganda, analisis koefisien determinasi, analisis t-tes dan Ftes. Hasil penelitian menunjukkan volume penjualan kamar berpengaruh terhadap laba bersih pada Hotel Grand Wijaya Singaraja tahun 2014-2016. Hal ini ditunjukkan dari hasil analisis t-tes yang menunjukkan bahwa nilai t-hitung $=16,355$ lebih besar dari t-tabel $=$ 2,03. Biaya operasional berpengaruh terhadap laba bersih pada Hotel Grand Wijaya Singaraja tahun 2014-2016. Hal ini ditunjukkan dari hasil analisis t-tes yang menunjukkan bahwa nilai t-hitung $=6,919$ lebih besar dari t-tabel $=2,03$. Volume penjualan kamar dan biaya operasional berpengaruh terhadap laba bersih pada Hotel Grand Wijaya Singaraja tahun 2014-2016. Hal ini ditunjukkan dari hasil analisis F-tes yang menunjukkan bahwa nilai F-hitung $=133,980$ lebih besar dari $F$-tabel $=4,13$. Besarnya pengaruh volume penjualan kamar dan biaya operasional terhadap laba bersih pada Hotel Grand Wijaya Singaraja tahun $2014-2016$ adalah sebesar $88,4 \%$, sedangkan sisanya sebesar $11,6 \%$ dipengaruhi oleh faktor-faktor lain yang tidak termasuk dalam penelitian ini.
\end{abstract}

Kata kunci: biaya operasional, laba bersih, volume penjualan

\begin{abstract}
This research aimed to know the influence of the volume of room sales and operational cost partially and simultaneously at Grand Wijaya Hotel Singaraja in 2014 to 2016. This is casual research with quantitative approaching. The data was collected by documentation method. The data analyzed using linear regression multiple, analysis coefficients determination, analysis t-test and F-test. The result of the research is showed that the room sales volume is influential through net profit at Grand Wijaya Hotel Singaraja in 2014 to 2016 . In this case is analysed using t-test that show the vaule t-count $=16,355$ is more than t-table $=2,03$. The operational cost is influence through net profit at Grand Wijaya Hotel Singaraja in 2014 to 2016. That is analysed through t-test is show that value $\mathrm{t}$-count $=6,919$ is more than $\mathrm{t}$-table $=2,03$. The volume of room sales and operational cost are influential through net profit at Grand Wijaya Hotel Singaraja in 2014 to 2016. In this case, the result of analysing F-test that show value of F-count $=133,980$ is more than F-table $=4,13$. The influence of the volume of room sales and operational cost through net profit at Grand Wijaya Hotel Singaraja in 2014 to 2016 is $88,4 \%$ while the rest is $11,6 \%$ is influence by another factor which is not included in this research.
\end{abstract}

Keywords: net profit, operational cost, sales volume

\section{PENDAHULUAN}


Laba atau keuntungan merupakan salah satu tujuan utama bagi perusahaan dalam menjalankan aktivitasnya (Kasmir, 2016). Laba merupakan indikator keberhasilan bagi perusahaan yang berorientasi pada laba, karena biasanya keberhasilan dari suatu perusahaan tersebut dilihat dari jumlah laba yang diperolehnya pada periode tertentu. Laba merupakan keuntungan atas upaya perusahaan dalam menghasilkan dan menjual barang atau jasanya (Suwardjono, 2008:464). Selain itu, Hery (2013:46) menyatakan, laba bersih berasal dari transaksi pendapatan, beban, keuntungan, dan kerugian. Transaksi transaksi ini diikhtisarkan dalam laporan laba rugi. Laba dihasilkan dari selisih antara sumber daya masuk (pendapatan dan keuntungan) dengan sumber daya keluar (beban dan kerugian) selama periode tertentu. Laba yang diperoleh perusahaan akan dapat digunakan untuk berbagai kepentingan oleh pemilik dan manajemen. Melalui laba ini, perusahaan dapat tumbuh dan berkembang, dapat menggunakan kemampuan yang lebih besar, dapat memberikan tingkat kepuasan yang lebih besar pada konsumen, serta dapat memperkuat kondisi perekonomian secara keseluruhan (Basu Swastha, 2002). Agar diperoleh laba sesuai dengan yang dikehendaki, perusahaan perlu menyusun perencanaan laba yang baik. Hal tersebut ditentukan oleh kemampuan perusahaan memprediksi kondisi usaha pada masa yang akan datang yang penuh ketidakpastian, serta mengamati kemungkinan faktor-faktor yang dapat mempengaruhi laba.

Terdapat tiga faktor yang mempengaruhi laba yaitu biaya, harga jual, dan volume penjualan atau produksi (Mulyadi, 2001). Selain itu, Munawir (2012) juga berpendapat bahwa beberapa faktor yang dapat mempengaruhi pencapaian laba yang besar baik dalam perencanaan maupun realisasinya yaitu, perusahaan harus mampu menekan biaya produksi maupun biaya operasi serendah mungkin dengan mempertahankan tingkat harga jual dan volume penjualan yang ada, perusahaan mampu menentukan harga jual sedemikian rupa sesuai dengan laba yang dikehendaki, dan mampu meningkatkan volume penjualan sebesar mungkin. Selain itu ada pula beberapa faktor yang mempengaruhi perubahan laba bersih (Indrawan, 2012). Faktor-faktor tersebut yaitu, naik turunnya jumlah unit yang dijual dan harga jual per unit, naik turunnya harga pokok penjualan. Perubahan harga pokok penjualan ini dipengaruhi oleh jumlah unit yang dibeli atau diproduksi atau dijual dan harga pembelian per unit atau harga pokok per unit, naik turunnya biaya usaha yang dipengaruhi oleh jumlah unit yang dijual, variasi jumlah unit yang dijual, variasi dalam tingkat harga dan efisiensi operasi perusahaan, naik turunnya pos penghasilan atau biaya non operasional yang dipengaruhi oleh variasi jumlah unit yang dijual, variasi dalam tingkat harga dan perubahan kebijaksanaan dalam pemberian atau penerimaan discount, naik turunnya pajak perseroan yang dipengaruhi oleh besar kecilnya laba yang diperoleh atau tinggi rendahnya tarif pajak dan adanya perubahan dalam metode akuntansi.

Berdasarkan penelitian yang dilakukan oleh Bayu Wisesa (2014) banyak cara akan ditempuh untuk mendapatkan laba yang lebih besar, salah satunya yang dapat digunakan untuk memperoleh laba yang optimal adalah dengan memperhatikan volume penjualan serta menekan biaya-biaya operasional yang akan dikeluarkan perusahaan. Munawir (2012) juga memberikan pendapat bahwa, untuk dapat mencapai laba bersih yang besar dalam perencanaan maupun realisasinya manajemen dapat melakukan berbagai langkah, salah satunya adalah dengan meningkatkan volume penjualan sebesar mungkin.

Volume penjualan adalah jumlah barang yang terjual dalam bentuk uang untuk jangka waktu tertentu dan didalamnya mempunyai strategi pelayanan yang baik Kotler (2002:68). 
Selain itu, menurut Aliminsyah dan Padji (2003:126), volume penjualan merupakan total penjualan yang berhasil dicapai atau ingin dicapai oleh suatu perusahaan pada periode tertentu. Bila dihubungkan dengan usaha jasa hotel, maka volume penjualan kamar merupakan jumlah kamar yang terjual dalam bentuk uang pada periode tertentu yang berhasil dicapai oleh hotel itu sendiri. Berikutnya menurut Jopie Jusuf (2006:33), biaya operasi atau biaya operasional adalah biaya-biaya yang tidak berhubungan langsung dengan produk perusahaan tetapi berkaitan dengan aktivitas operasi perusahaan sehari-hari.

Indikator pengukuran biaya operasional adalah dengan menjumlahkan biaya administrasi umum, biaya penyusutan, biaya pemasaran, dan biaya lain-lain (Ismail, 2010). Sedangkan Kasmir (2011) biaya operasional dapat dihitung dengan menjumlahkan biaya gaji pegawai, biaya administrasi, biaya pemeliharaan, dan biaya lain-lain. Selanjutnya Lukman (2001) menyebutkan indikator biaya operasional adalah dengan menjumlahkan biaya penyusutan, biaya pemasaran, biaya administrasi umum dan biaya operasional lainnya. Jadi, dapat disimpulkan indikator pengukuran biaya operasional adalah dengan menjumlahkan biaya penyusutan, biaya administrasi umum, biaya gaji pegawai, biaya pemasaran dan biaya oeprasional lainnya.

Terdapat hubungan yang erat antara volume penjualan dengan laba bersih. Horngren (2000) hubungan tersebut dikatakan memiliki hubungan yang sempurna yaitu apabila volume penjualan naik maka laba bersih juga akan naik, begitu juga sebaliknya apabila volume penjualan turun maka laba juga akan turun. Selanjutnya pendapat dari Jopie Jusuf (2006) bahwa, bila perusahaan dapat menekan biaya operasional, maka perusahaan akan dapat meningkatkan laba, demikian juga sebaliknya, bila terjadi pemborosan biaya akan mengakibatkan menurunnya laba.

Hotel Grand Wijaya merupakan salah satu City Hotel yang berlokasi di Kota Singaraja. Tamu hotel yang menginap lebih didominasi oleh tamu domestik. Baik tamu umum maupun tamu dari Pemerintah Daerah Kabupaten Buleleng. Tidak hanya untuk menginap saja tetapi ada juga terkadang tamu yang hanya menyewa fasilitas lain dari hotel seperti tempat untuk meeting. Jenis kamar yang tersedia pada hotel Grand Wijaya Singaraja adalah Economy, AC Standar, Superior, dan Deluxe Room. Beberapa fasilitas lainnya yang disediakan berupa restoran, meeting room, transport, rentcar, dan laundry. Berbicara tentang hotel, tentu saja yang menjadi produk utamanya adalah kamar, sehingga volume penjualan kamar mestinya akan berpengaruh terhadap laba perusahaan yang akan didapat. Masalah yang masih dihadapi oleh Hotel Grand Wijaya Singaraja dalam menjalankan usahanya adalah laba bersih pada tahun 2014 sampai 2016 selalu mengalami peningkatan dan penurunan yang signifikan. Pada tahun 2014 tepatnya bulan Desember dan pada tahun 2015 tepatnya bulan Mei pihak hotel mengalami rugi bersih.

Pada penelitian awal dapat diketahui bahwa, pada tahun 2014 bulan Januari laba bersih yang diperoleh sebesar Rp 12.104.493. Selanjutnya pada bulan Februari meningkat menjadi $\mathrm{Rp}$ 20.060.458 bulan berikutnya yaitu Maret laba bersih mengalami penurunan yang sangat drastis menjadi $\mathrm{Rp}$ 4.466.966. Kemudian pada bulan April meningkat kembali menjadi Rp 14.223.272 dan pada bulan Mei laba bersih menurun menjadi Rp 5.260.503. Selanjutnya pada bulan Juni laba bersih menurun kembali menjadi Rp 4.920.089. Lebih lanjut bulan Juli sampai September berturut-turut mengalami peningkatan yaitu bulan Juli Rp 6.715.674. Bulan Agustus $\mathrm{Rp}$ 14.336.594, serta bulan September $R p$ 15.696.268. Kemudian tiga bulan selanjutnya laba bersih kembali mengalami penurunan yaitu bulan Oktober menjadi Rp 13.850.082 selanjutnya bulan November menjadi Rp 8.861.016. Terakhir pada bulan Desember terjadi rugi bersih sebesar Rp 10.304.576. 
Lebih lanjut pada tahun 2015, bulan Januari sampai bulan Maret laba bersih hotel mengalami penurunan berturut-turut. Pada bulan Januari $R p$ 4.103.994 kemudian bulan Februari menjadi Rp 3.084.842 dan pada bulan Maret menjadi Rp 2.629.637. Selanjutnya pada bulan April meningkat menjadi $\mathrm{Rp}$ 6.142.825, namun berikutnya pada bulan Mei terjadi rugi bersih sebesar $\mathrm{Rp}$ 11.154.804. Kemudian pada bulan Juni dan Juli laba bersih meningkat kembali yaitu, pada bulan Juni menjadi $R p$ 2.022.089, dan bulan Juli sebesar $R p$ 16.338.028. Lebih lanjut bulan Agustus menurun kembali menjadi $\mathrm{Rp} \mathrm{6.927.484.}$ Berikutnya pada bulan September dan Oktober laba bersih mengalami peningkatan yang cukup signifikan yaitu pada bulan September sebesar Rp 39.724.933, dan pada bulan Oktober menjadi Rp 51.346.897. Selanjutnya pada bulan November laba bersih kembali menurun menjadi Rp 10.173.438. Terakhir pada bulan Desember meningkat kembali menjadi Rp 23.625.611.

Berikutnya pada tahun 2016, laba bersih pada bulan Januari sebesar $R p$ 8.542.090 selanjutnya pada bulan Februari mengalami penurunan menjadi Rp 7.144.831. Pada bulan Maret laba bersih meningkat drastis menjadi $\mathrm{Rp}$ 21.207.183. Bulan berikutnya pada bulan April dan Mei laba bersih turun kembali yaitu pada bulan April menjadi $R p$ 18.318.195, dan pada bulan Mei menjadi Rp 3.313.007. Lebih lanjut pada bulan Juni sampai Agustus laba bersih meningkat kembali secara berturut-turut. Bulan Juni laba bersih sebesar Rp 8.929.084 kemudian bulan Juli sebesar Rp 32.434.463, dan bulan Agustus menjadi Rp 34.844.008. Selanjutnya pada bulan September kembali menurun menjadi $\mathrm{Rp}$ 25.992.264. Bulan Oktober meningkat kembali menjadi Rp 27.858.891. Berikutnya bulan November menurun kembali menjadi Rp 26.651.282. Terakhir pada bulan Desember laba bersih meningkat kembali menjadi $\mathrm{Rp}$ 47.989.836.

Berdasarkan penjelasan tersebut dapat diketahui bahwa perkembangan laba bersih Hotel Grand Wijaya Singaraja cenderung mengalami fluktuasi, hal tersebut dapat dilihat dari laporan keuangan Hotel Grand Wijaya Singaraja tahun 2014-2016. Fluktuasi laba bersih ini terjadi karena volume penjualan kamar tidak dapat selalu meningkat setiap bulannya. Oleh karena itu, usaha jasa perhotelan dikatakan sebagai usaha yang bersifat musiman. Selain volume penjualan kamar, biaya operasional hotel juga ikut berfluktuasi karena aktivitas operasi hotel tiap bulannya tidak akan sama sehingga laba bersih akan ikut berfluktuasi. Adapun yang menjadi tujuan dalam penelitian ini adalah untuk mengetahui pengaruh volume penjualan kamar dan biaya operasional terhadap laba bersih baik secara parsial maupun simultan pada Hotel Grand Wijaya Singaraja tahun 2014-2016.

\section{METODE}

Jenis penelitian ini adalah penelitian kausal dengan menggunakan format eksplanasi. Menurut Riduwan (2008:165), penelitian kausal (sebabakibat) adalah jenis penelitian yang menjelaskan hubungan yang bersifat mempengaruhi antara dua variabel atau lebih.

Penelitian ini menggunakan pendekatan kuantitatif, hal ini dikarenakan data yang digunakan berupa angkaangka. Kemudian, variabel bebas dalam penelitian ini adalah volume penjualan kamar dan biaya operasional, sedangkan variabel terikatnya adalah laba bersih.

Adapun hasil yang diharapkan dari penelitian ini adalah adanya pengaruh volume penjualan kamar dan biaya operasional terhadap laba bersih baik secara simultan maupun parsial pada Hotel Grand Wijaya Singaraja tahun 20142016. Rancangan penelitian ini dapat dilihat pada gambar 1 . 


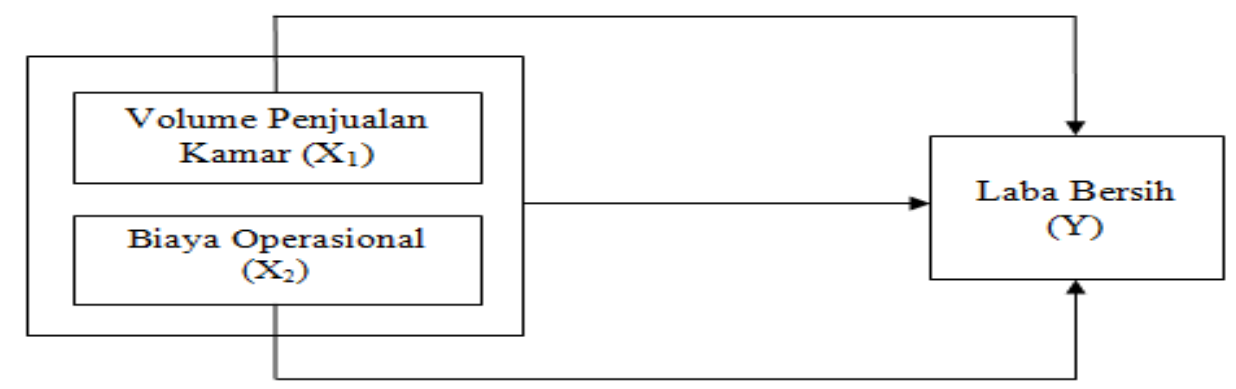

Gambar 1. Rancangan Penelitian

Lokasi penelitian ini bertempat di Hotel Grand Wijaya yang beralamat di Jalan Sudirman No. 74 Singaraja, Kabupaten Buleleng.

Subjek dalam penelitian ini adalah Hotel Grand Wijaya Singaraja, sedangkan objek dalam penelitian ini adalah volume penjualan kamar (X1), biaya operasional (X2), dan laba bersih (Y) pada Hotel Grand Wijaya Singaraja tahun 2014-2016.

Definisi operasional variabel dalam penelitian ini adalah volume penjualan merupakan total penjualan yang berhasil dicapai atau ingin dicapai oleh suatu perusahaan pada periode tertentu (Aliminsyah dan Padji, 2003:126). Biaya operasi atau biaya operasional adalah biaya-biaya yang tidak berhubungan langsung dengan produk perusahaan tetapi berkaitan dengan aktivitas operasi perusahaan sehari-hari (Jopie Jusuf, 2006:33). Dalam hal ini, biaya operasional yang timbul akibat adanya aktivitas operasional hotel terdiri dari biaya penyusutan, biaya administrasi dan umum, serta biaya operasional lainnya. Biaya Penyusutan adalah proses penyisihan sejumlah uang atau biaya atas harta atau asset yang dipakai untuk menghasilkan pendapatan atau sebagai sejumlah biaya yang dikumpulkan dalam periode tertentu terhadap harta atau asset yang dipakai dalam proses untuk mendapatkan pendapatan, akan tetapi ini bukan berarti pengumpulan sejumlah dana untuk mengganti asset. Dalam penelitian ini biaya penyusutan yang dimaksud yaitu penyusutan gedung, kendaraan operasional hotel, dan penyusutan peralatan. Biaya administrasi dan umum merupakan suatu pengorbanan perusahaan untuk keperluan administrasi kantor perusahaan dan umum. Dalam penelitian ini biaya administrasi dan umum yang dimaksud meliputi biaya gaji pegawai, tunjangan-tunjangan, biaya listrik, air, telepon, biaya pajak, biaya keperluan front office. Biaya operasional lainnya yang dimaksud dalam penelitian ini meliputi biaya keperluan dapur, upacara keagamaan, laundry, iuran sampah, koran bulanan. laba bersih adalah perbedaan antara pendapatan dengan beban, jika pendapatan melebihi beban maka hasilnya laba bersih (Henry Simamora, 2000:25).

Jenis data yang digunakan dalam penelitian ini adalah data kuantitatif berupa laporan keuangan Hotel Grand Wijaya Singaraja tahun 2014-2016 dengan fokus utamanya pada data volume penjualan kamar, biaya operasional, dan laba bersih. Sumber data yang digunakan dalam penelitian ini adalah data sekunder yang diperoleh dari laporan keuangan Hotel Grand Wijaya Singaraja tahun 20142016.

Metode pengumpulan data yang digunakan dalam penelitian ini adalah dengan metode dokumentasi yaitu dengan mencari data melalui dokumen dan arsip berupa laporan keuangan hotel Hotel Grand Wijaya Singaraja terkait dengan data volume penjualan kamar, biaya operasional dan laba bersih periode 20142016.

Metode analisis data dalam penelitian ini menggunakan analisis regresi linier berganda dengan berbantuan program komputer SPSS (Statistical Product and Service Solution).

Analisis regresi linier berganda dilakukan untuk mengetahui sejauh mana 
variabel bebas mempengaruhi variabel terikat.

Tahap analisis yang dilakukan adalah pertama, uji asumsi klasik yang terdiri dari uji normalitas, uji multikolinieritas, uji heteroskedastisitas, dan uji autokorelasi. Menurut Suliyanto (2011:69), uji normalitas dilakukan untuk mengetahui apakah dalam model regresi variabel terikat dan variabel bebas memiliki distribusi normal atau tidak.

Model regresi yang baik adalah memiliki data normal atau mendekati normal. Pengujian normalitas dilakukan dengan menggunakan One sample Kolmogorov-Smirnov Test, dengan melihat tingkat signifikansi $5 \%$.

Berikutnya uji multikolinearitas bertujuan untuk menguji apakah dalam model regresi yang terbentuk ada korelasi yang tinggi atau sempurna diantara variabel bebas atau tidak. Jika dalam model regresi yang terbentuk terdapat korelasi yang tinggi atau sempurna diantara variabel bebas maka model regresi tersebut dinyatakan mengandung gejala multikolinier. Uji multikolinieritas dapat dilakukan dengan melihat nilai TOL (Tollerance) dan Variance Inflation Factor (VIF) dari masing-masing variabel bebas terhadap variabel terikatnya (Suliyanto, 2011:81).

Kemudian uji heteroskedastisitas berarti ada varian variabel pada model regresi yang tidak sama (konstan). Sebaliknya, jika varian variabel pada model regresi memiliki nilai yang sama (konstan) maka disebut dengan homoskedastisitas. Pengujian heteroskedastisitas dapat dilakukan dengan menggunakan uji Glejser.

Berikutnya yaitu uji autokorelasi bertujuan untuk mengetahui apakah ada korelasi antara anggota serangkaian data observasi yang diuraikan menurut waktu (time series) atau ruang (cross section). Deteksi autokorelasi dilakukan dengan uji Durbin Watson Test. Tahap kedua, yaitu analisis regresi linier berganda. Analisis regresi linier berganda dilakukan untuk mengetahui sejauh mana variabel bebas mempengaruhi variabel terikat.

Menurut Suliyanto (2011:53), dalam analisis regresi linier berganda terdapat satu variabel terikat dan lebih dari satu variabel bebas. Dalam penelitian ini penulis menggunakan analisis regresi linier berganda karena terdapat dua variabel bebas yang akan diteliti. Analisis Regresi linier berganda ini digunakan untuk memproyeksikan dan mencari pengaruh dan hubungan terhadap variabel terikat (Y).

Tahap ketiga, yaitu uji statistik yang terdiri dari uji parsial (Uji t) dan uji simultan (Uji $F)$. Uji t dilakukan untuk menguji pengaruh variabel bebas terhadap variabel terikat secara parsial. Pengujian dilakukan dengan membandingkan t-hitung dengan t-tabel pada tingkat signifikan $(\alpha)=5 \%$. Kriteria pengambilan keputusan pada uji t adalah sebagai berikut. $\mathrm{HO}$ diterima bila t-hitung < t-tabel dan Ha diterima bila t-hitung $\geq \mathrm{t}$ tabel. Sedangkan Uji F pada dasarnya menunjukkan apakah semua variabel bebas yang dimasukkan dalam model mempunyai pengaruh secara simultan atau bersama-sama terhadap variabel terikat. Pada penelitian ini F-hitung akan dibandingkan dengan nilai F-tabel pada tingkat signifikan $(\alpha)=5 \%$. Kriteria penilaian hipotesis pada uji $\mathrm{F}$ adalah $\mathrm{HO}$ diterima apabila F-hitung $<$ F-tabel dan $\mathrm{Ha}$ diterima apabila F-hitung $\geq$ F-tabel.

\section{HASIL DAN PEMBAHASAN Hasil}

Pengaruh volume penjualan kamar terhadap laba bersih pada Hotel Grand Wijaya Singaraja tahun 2014-2016 secara parsial dapat diketahui melalui hasil analisis t-tes dengan menggunakan program SPSS (Statistical Product and Service Solution) 24.0 for windows. Hasil analisis tersebut menunjukkan bahwa pengaruh volume penjualan kamar terhadap laba bersih pada hotel Grand Wijaya Singaraja tahun 2014-2016 dapat dilihat pada tabel 1. 
Coefficients $^{\mathrm{a}}$

\begin{tabular}{|c|c|c|c|c|c|}
\hline \multirow{2}{*}{ Model } & \multicolumn{2}{|c|}{ Unstandardized Coefficients } & \multirow{2}{*}{$\begin{array}{c}\text { Standardized } \\
\text { Coefficients } \\
\text { Beta }\end{array}$} & \multirow{2}{*}{$\mathrm{t}$} & \multirow{2}{*}{ Sig. } \\
\hline & $\mathrm{B}$ & Std. Error & & & \\
\hline 1 (Constant) & -25845031.280 & 6302624.679 & & -4.101 & .000 \\
\hline $\begin{array}{l}\text { Volume } \\
\text { penjualan }\end{array}$ & 1.497 & .092 & 1.021 & 16.355 & .000 \\
\hline
\end{tabular}

Berdasarkan hasil analisis pada tabel 1 dapat dilihat nilai t-hitung untuk volume penjualan adalah sebesar 16,355. Jika dibandingkan dengan t-tabel pada taraf signifikansi 5\% $(\alpha=0,05)$ maka, nilai thitung lebih besar, sehingga $\mathrm{HO}$ ditolak dan Ha diterima. Hal ini berarti secara parsial terdapat pengaruh volume penjualan kamar terhadap laba bersih.
Pengaruh biaya operasional terhadap laba bersih pada Hotel Grand Wijaya Singaraja tahun 2014-2016 secara parsial dapat diketahui dari hasil analisis t-tes dengan menggunakan program SPSS 24.0 for windows. Hasil analisis tersebut menunjukkan bahwa pengaruh biaya operasional terhadap laba bersih pada hotel dapat dilihat pada tabel 2 .

Tabel 2. Hasil Uji Statistik Parsial (Uji t)

Coefficients $^{a}$

\begin{tabular}{|c|c|c|c|c|c|}
\hline \multirow{2}{*}{ Model } & \multicolumn{2}{|c|}{ Unstandardized Coefficients } & \multirow{2}{*}{$\begin{array}{c}\text { Standardized } \\
\text { Coefficients } \\
\text { Beta }\end{array}$} & \multirow{2}{*}{$\mathrm{t}$} & \multirow{2}{*}{ Sig. } \\
\hline & B & Std. Error & & & \\
\hline 1 (Constant) & -25845031.280 & 6302624.679 & & -4.101 & .000 \\
\hline $\begin{array}{l}\text { Biaya } \\
\text { operasional }\end{array}$ & -.786 & .114 & -.432 & -6.919 & .000 \\
\hline
\end{tabular}

Berdasarkan hasil analisis pada tabel 2 dapat dilihat nilai t-hitung untuk biaya operasional adalah sebesar 6.919. Jika dibandingkan dengan t-tabel pada taraf signifikansi sebesar $5 \% \quad(\alpha=0,05)$ maka, nilai t-hitung lebih besar, sehingga $\mathrm{HO}$ ditolak dan $\mathrm{Ha}$ diterima. Hal ini berarti secara parsial terdapat pengaruh biaya operasional terhadap laba bersih pada Hotel Grand Wijaya Singaraja tahun 20142016. Pengaruh volume penjualan kamar dan biaya operasional terhadap laba bersih pada Hotel Grand Wijaya Singaraja tahun 2014-2016 secara simultan dapat dilakukan dengan menggunakan uji $F$ dengan bantuan program SPSS 24.0 for windows. Uji $\mathrm{F}$ ini menunjukkan analisis regresi linier berganda variabel bebas yaitu volume penjualan kamar (X1) dan biaya operasional (X2) memiliki pengaruh secara simultan terhadap variabel terikat yaitu laba bersih ( $\mathrm{Y}$ ). Hasil analisis uji $\mathrm{F}$ tersebut diperoleh hasil seperti terlihat pada tabel 3.

Tabel 3. Hasil Uji Statistik Simultan (Uji F) ANOVA $^{a}$

\begin{tabular}{|c|c|c|c|c|c|c|}
\hline \multicolumn{2}{|c|}{ Model } & \multirow{2}{*}{$\begin{array}{r}\text { Sum of Squares } \\
6111026285000000.00 \\
0\end{array}$} & \multirow{2}{*}{$\frac{d f}{2}$} & \multirow{2}{*}{$\begin{array}{c}\text { Mean Square } \\
3055513143000000.00 \\
0\end{array}$} & \multirow{2}{*}{$\frac{F}{133.980}$} & \multirow{2}{*}{$\begin{array}{l}\text { Sig. } \\
.000^{\mathrm{b}}\end{array}$} \\
\hline 1 & Regression & & & & & \\
\hline & Residual & 752587557700000.000 & 33 & 22805683570000.000 & & \\
\hline & Total & $\begin{array}{r}6863613843000000.00 \\
0\end{array}$ & 35 & & & \\
\hline
\end{tabular}


Berdasarkan hasil analisis pada tabel 3 menunjukkan bahwa F-hitung = 133,980. Hasil analisis F-tes memperlihatkan nilai F-hitung sebesar 133,980 sedangkan nilai F-tabel sebesar 4,13 .

Selanjutnya t-hitung dan F-tabell dibandingkan dan hasil analisi memperlihatkan bahwa nilai F-hitung $>$ Ftabel $(133,980>4,13)$ dengan taraf signifikansi $0,000<0,05$, sehingga $\mathrm{HO}$ ditolak dan Ha diterima. Dengan demikian dapat disimpulkan bahwa volume penjualan kamar dan biaya operasional memiliki pengaruh yang signifikan secara simultan terhadap laba bersih. Untuk mengetahui besarnya pengaruh volume penjualan kamar dan biaya operasional terhadap laba bersih pada Hotel Grand Wijaya Singaraja tahun 2014-2016 maka, dapat digunakan analisis koefisien determinasi (Adjusted $R$ Square).

Besarnya koefisien determinasi dapat dilihat pada tabel 4 berikut..

Tabel 4. Hasil Uji Koefisien Determinasi (Adjusted R Square) Model Summary ${ }^{b}$

\begin{tabular}{|c|c|c|c|c|}
\hline Model & $\mathrm{R}$ & R Squares & $\begin{array}{l}\text { Adjusted R } \\
\text { Squares }\end{array}$ & $\begin{array}{l}\text { Std. Error of the } \\
\text { Estimate }\end{array}$ \\
\hline 1 & $.944^{a}$ & .890 & .884 & 4775529.663 \\
\hline
\end{tabular}

Berdasarkan hasil analisis pada tabel 4 menunjukkan bahwa besarnya pengaruh volume penjualan kamar dan biaya operasional terhadap laba bersih adalah sebesar 0,884 yang berarti bahwa sumbangan pengaruh untuk variabel volume penjualan kamar (X1) dan biaya operasional (X2) terhadap laba bersih (Y) adalah sebesar $88,4 \%$.

Jadi, dalam hal ini dapat dikatakan bahwa laba bersih pada Hotel Grand Wijaya Singaraja tahun 2014-2016 sebesar $88,4 \%$ ditentukan oleh variabel volume penjualan kamar dan biaya operasional, sedangkan sisanya sebesar $11,6 \%$ dipengaruhi oleh faktor-faktor lain yang tidak termasuk dalam penelitian ini.

\section{Pembahasan}

Berdasarkan hipotesis yang diajukan dalam penelitian ini, bahwa ada pengaruh yang signifikan volume penjualan kamar secara parsial terhadap laba bersih pada Hotel Grand Wijaya Singaraja tahun 2014-2016 dapat diterima. Hal ini berarti tinggi rendahnya volume penjualan akan berpengaruh terhadap perolehan laba bersih. Sesuai dengan pendapat Horngren (2000) hubungan antara volume penjualan dengan laba bersih dikatakan memiliki hubungan yang sempurna yaitu apabila volume penjualan naik maka laba bersih juga akan naik, begitu juga sebaliknya apabila volume penjualan turun maka laba bersih juga akan turun. Hal ini sejalan dengan hasil penelitian terdahulu yang dilakukan oleh Sumayah (2011) bahwa, volume penjualan berpengaruh positif dan signifikan terhadap laba bersih. Hal ini berarti antara volume penjualan dengan laba bersih memiliki hubungan positif searah.

Berdasarkan hipotesis yang diajukan dalam penelitian ini, bahwa ada pengaruh yang signifikan dari biaya operasional secara parsial terhadap laba bersih pada Hotel Grand Wijaya Singaraja tahun 2014-2016 dapat diterima. Hal ini berarti tinggi rendahnya biaya operasional yang dikeluarkan oleh perusahaan akan mempengaruhi tinggi rendahnya laba bersih yang diperoleh. Temuan ini sesuai dengan pendapat Jopie Jusuf (2006) bahwa, bila perusahaan dapat menekan biaya operasional maka perusahaan akan dapat meningkatkan laba bersih, demikian juga sebaliknya bila terjadi pemborosan biaya akan mengakibatkan menurunnya laba.

Hal ini sejalan dengan hasil penelitian terdahulu yang dilakukan oleh I 
Wayan Bayu Wisesa (2014) bahwa, biaya operasional berpengaruh negatif dan signifikan terhadap laba bersih. Artinya, semakin besar biaya operasional maka perolehan laba akan semakin kecil, dan begitu pula sebaliknya semakin kecil biaya operasional maka perolehan laba akan semakin besar. Hal ini berarti antara biaya operasional dengan laba bersih memiliki hubungan yang negatif tidak searah.

Berdasarkan hasil penelitian bahwa, volume penjualan kamar dan biaya operasional memiliki pengaruh yang signifikan secara simultan terhadap laba bersih pada Hotel Grand wijaya Singaraja tahun 2014-2016. Berdasarkan pendapat Budi Rahardjo (2007) bahwa, adanya hubungan yang erat mengenai volume penjualan terhadap peningkatan laba bersih perusahaan, karena dalam hal ini laba akan timbul jika penjualan produk lebih besar dibandingkan dengan biayabiaya yang dikeluarkan.

Teori tersebut menunjukkan bahwa untuk meningkatkan laba bersih maka, volume penjualan pada suatu perusahaan harus meningkat serta biaya yang digunakan harus efisien dan biaya tersebut harus lebih kecil dari pendapatan yang diperoleh. Dengan meningkatnya volume penjualan, penggunaan biaya yang efisien serta laba bersih yang diperoleh meningkat maka, akan membawa keuntungan bagi perusahaan. Hal ini dapat dibuktikan melalui persamaan regresi yang dihasilkan sebagai berikut.

$\gamma=\alpha+\beta 1 X 1+\beta 2 X 2$

$\gamma=25.845 .031,280+1,497 X 1-0,786 X 2$

Artinya, koefisien regresi volume penjualan (X1) sebesar 1,497 berarti apabila terdapat penambahan volume penjualan sebesar 1 satuan, maka laba (Y) meningkat sebesar 1,497. Begitu juga sebaliknya apabila terdapat penurunan volume penjualan sebesar 1 satuan maka, laba (Y) menurun sebesar 1,497. Selanjutnya koefisien regresi biaya operasional (X2) sebesar -0,879 berarti apabila terdapat penambahan biaya operasional sebesar 1 satuan makan laba (Y) menurun sebesar 0,879. Begitu pula sebaliknya apabila terdapat penurunan biaya operasional sebesar 1 satuan maka, laba (Y) meningkat sebesar 0,879.

Berikutnya besar pengaruh volume penjualan kamar dan biaya operasional terhadap laba bersih dapat dilihat pada koefisien determinasi sebesar 0,884 yang berarti sumbangan pengaruh untuk variabel volume penjualan kamar dan biaya operasional terhadap laba bersih adalah sebesar $88,4 \%$, sedangkan sisanya sebesar $11,6 \%$ dipengaruhi oleh faktor-faktor lain yang tidak termasuk dalam penelitian ini.

\section{SIMPULAN DAN SARAN Simpulan}

Berdasarkan hasil analisis data, maka dapat dibuat simpulan hal-hal sebagai berikut. Volume penjualan kamar mempunyai pengaruh yang signifikan secara parsial terhadap laba bersih pada Hotel Grand Wijaya Singaraja tahun 20142016. Hal ini ditunjukkan dari hasil analisis ttes yang menunjukkan bahwa nilai thitung lebih besar dari ttabel $(16,355>$ 2,03) dengan taraf signifikansi $0,000<$ 0,05 . Biaya operasional mempunyai pengaruh yang signifikan secara parsial terhadap laba bersih pada Hotel Grand Wijaya Singaraja tahun 2014-2016. Hal ini ditunjukkan dari hasil analisis t-tes yang menunjukkan bahwa nilai t-hitung lebih besar dari t-tabel $(6,919>2,03)$ dengan taraf signifikansi $0,000<0,05$. Secara simultan volume penjualan kamar dan biaya operasional memiliki pengaruh yang signifikan terhadap laba bersih pada Hotel Grand Wijaya Singaraja tahun 2014-2016. $\mathrm{Hal}$ ini ditunjukkan dari hasil analisis $\mathrm{F}$-tes yang menunjukkan bahwa nilai F-hitung lebih besar dari F-tabel $(133,980>4,13)$ dengan taraf signifikansi $0,000<0,05$.

\section{Saran}

Berdasarkan simpulan di atas maka, dapat diberikan saran sebagai berikut. Bagi pihak hotel, diharapkan agar dapat lebih memperhatikan kembali besarnya pendapatan dan biaya sehingga laba yang diperoleh tidak menunjukkan nilai yang negatif. Hal ini dapat dilakukan dengan cara meningkatkan volume 
penjualan kamar serta menekan jumlah biaya operasional yang harus dikeluarkan sehingga jumlah pendapatan yang diterima akan menunjukkan nilai yang lebih besar daripada jumlah biaya yang harus dikeluarkan maka, Bagi peneliti selanjutnya, sebaiknya tidak hanya menggunakan variabel volume penjualan dan biaya sebagai variabel bebas yang dapat mempengaruhi laba, tetapi dapat juga digunakan variabel lain seperti harga jual yang merupakan salah satu faktor penentu pula tinggi rendahnya suatu laba dalam suatu perusahaan.

\section{DAFTAR PUSTAKA}

Aliminsyah \& Padji. 2003. Kamus Istilah Akuntansi. Bandung: Yrama Widya.

Hery. 2013. Akuntansi Keuangan Menengah. CAPS (Control of Academic Publishing Service). Yogyakarta.

Horngren, Charles T. \& George Foster. 2000. Akuntansi Biaya Suatu Pendekatan, Alih Bahasa Marianus Sinaga. Jakarta: Erlangga.

Jusuf, Jopie. 2006. Analisis Kredit untuk Account Officer. Cetakan ketujuh, Jakarta: Ikrar Mandiriabadi.

Kasmir. 2016. Analisis Laporan Keuangan. Cetakan Ke-9. Jakarta: Rajawali Pers.

Kotler, Philip. 2002. Manajemen Pemasaran. Jilid 1. Edisi Milenium. Jakarta: Prehallindo

Mulyadi. 2001. Sistem Akuntansi, Edisi ke 3. Jakarta: Salemba Empat.

Munawir. 2012. Analisis Laporan Keuangan. Yogyakarta: LIBERTY.

Rahardjo, Budi. 2007. Keuangan dan Akuntansi untuk Manajer Non Keuangan. Yogyakarta: Graha IImu.

Riduwan. 2008. Metode dan Teknik Penyusunan Tesis. Bandung: Alfabeta.
Suliyanto. 2011. Ekonometrika Terapan: Teori dan Aplikasi dengan SPSS. Yogyakarta: ANDI.

Sumayah. 2011. Pengaruh Volume Penjualan dan Biaya Produksi Terhadap Laba Bersih. Skripsi (tidak diterbitkan). Program Studi Akuntansi Universitas Komputer Indonesia Bandung.

Suwardjono. 2008. Teori Akuntansi: Perekayasaan Pelaporan Keuangan. Yogyakarta: BPFE.

Swastha, Basu. 2002. M anajemen Penjualan. Yogyakarta: BPFE.

Wisesa, I Wayan Bayu. 2014. Pengaruh Volume Penjualan Mente Dan Biaya Operasional Terhadap Laba Bersih Pada UD. Agung Esha Karangasem Tahun 2013. Skripsi (tidak diterbitkan). Jurusan Pendidikan Ekonomi, Universitas Pendidikan Ganesha Singaraja. 